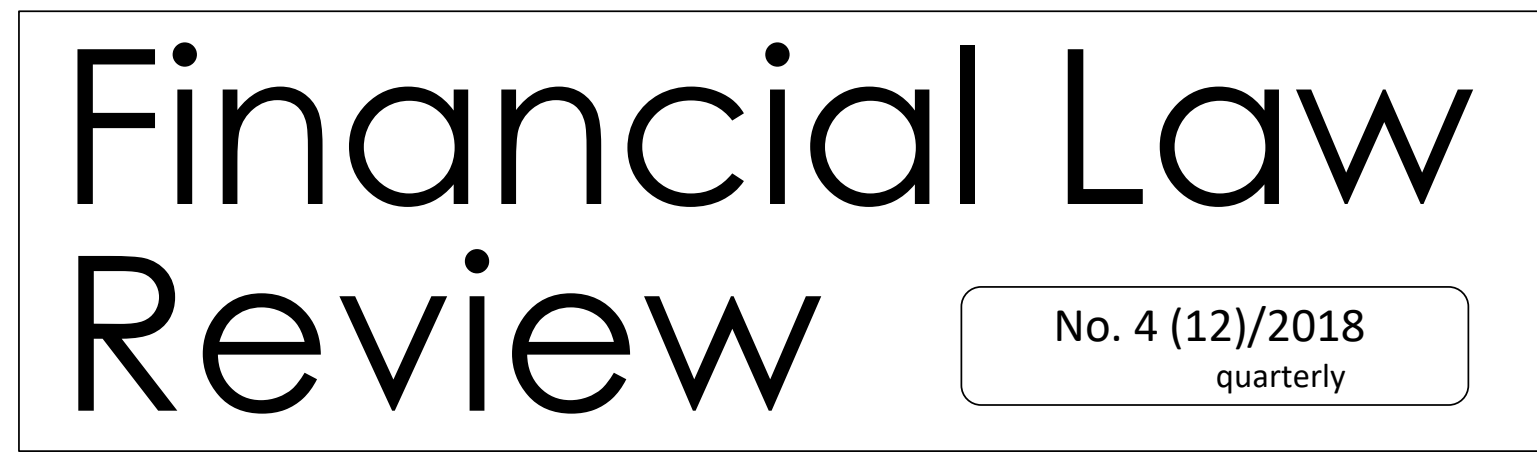

UNIVERSITY OF GDAŃSK • MASARYK UNIVERSITY • PAVEL JOZEF ŠAFÁRIK UNIVERSITY • UNIVERSITY OF VORONEZH http://www.ejournals.eu/FLR

\title{
THE ROLE OF THE FINANCIAL ADMINISTRATION BODIES IN THE PROCESS OF RETURNING UNJUSTLY USED PUBLIC FUNDS BACK INTO THE PUBLIC BUDGET
}

\author{
ANDREA VUONGOVÁ
}

\begin{abstract}
This article discusses the role of the Financial Administration in the process of returning unjustly used public funds back into the public budget. The introduction will focus on a brief explanation of the institute of the budgetary discipline breach and the activity of the Financial Administration in proceeding of the levy for the breach of budgetary discipline. In the next chapters will be describe the impact of judicial jurisprudence, the strengthening of the grant providers role and the associated practical problems faced by Financial Administration Bodies. The aim of the paper is to look at the position of the Financial Administration Bodies in the process of returning unjustly used public funds back into the public budget, while considering the various aspects that affect this activity.
\end{abstract}

Key words: budgetary discipline breach, levy, principle of proportionality, demand for grant repayment, non-payment of the grant

JEL Classification: K23, K40

\section{Introduction}


Public funds are an essential tool for financing of public administration tasks. An integral part of governance is ensuring the control of the handling of public funds and the observance of the purpose for which the public funds were intended. The detection of budgetary discipline breach and returning unjustly used public funds back to the public budget are some of the main components of the fragmented system of public finance control in the Czech Republic. The financial Administration Bodies, which are responsible for the administration of levy due to breach of budgetary discipline play an important role in this area.

The system of public budgets is managed by budgetary rules, which are summarized in the Czech Republic under two laws - the Budget Rules (hereinafter the "Budget Rules") and the Act on Budget Rules of Municipality Budgets.

Budgetary rules regulate situations where there is an unjustified use of public funds through the budget discipline breach institute. The finding of a breach of budgetary discipline is entrusted by the Budget Rules to the Financial Administration Bodies in the framework of the administration of a levy for breach of budgetary discipline. The Financial Administration Bodies are in charge of administering the levy for the breach of budgetary discipline under the Tax Code regime. During the tax proceedings, they disclose a budgetary discipline breach on the basis of their own control activities or on the grounds of suspicion of a budgetary discipline breach by another control authority. The result of tax proceedings is the issue of the adjustment notice for the levy of unjustly used public funds back to the public budget. The Financial Administration Bodies also ensure recovery of funds, decide on submitted appeals, supervisory measures and levy remission due to breach of budgetary discipline and a possible delay penalty.

Unjustified usage of public funds provided from the budget of self-governing municipalities is subject to a specific control regime directly under the self-governing municipality units. Although the Financial Administration Bodies are not acting in this process, the procedural rules of the Tax Code are also applied here. This area will not be part of further cementation.

The administration of levy due to breach of budgetary discipline is one of the main tools for returning unjustly used public funds back to the public budget (in particular the state budget and the National fund). In the following chapters I will deal with the activities of Financial Administration Bodies in the process of returning funds, with the strengthening of the grant providers competencies and judicial jurisprudence and its subsequent interference with the competences of Financial Administration Bodies.

\section{The Budgetary discipline breach}


Legislation of the budgetary discipline breach is contained in Title XII of the Budget Rules. Article 44 of the Budgetary Rules defines a breach of budgetary discipline, among other things, as "the unjustified use of funds of the state budget and other state funds and the unjustly use or retention of funds provided from the state budget, state fund, National fund or state financial assets." The term unjustly use of funds is further specified by the Act in the definition of terms in Article 3, which provides that "unjustified use of funds of the state budget, other state funds, funds provided from the state budget, state financial assets, state fund or National Fund means the expenditure of these funds that is in breach of the obligation laid down in a legal regulation, decision, or agreement to provide such funds, or in the breach of the purpose or the conditions under which the funds were included in the state budget or were moved by budgetary measures and were used in breach of the stated purpose or conditions."

The legislation distinguishes between unjustified use of public funds concentrated in the state budget and unjustified use of funds provided from the state budget, the state fund or, in the case of grants co-financed from European Union funds, from the National fund. Funds are provided through grants and non-repayable financial assistance. Grants can be defined as "finances from the state budget, state financial assets or the National Fund to legal or natural persons for a specific purpose" [Grossová 2008: 14]. There is an overwhelming majority of cases of breach of budgetary discipline in this area and, therefore, the substantial part of the activities of the Financial Administration Bodies in levy administration is focused here.

\section{The activities of Financial Administration Bodies in administration of levy due to breach of budgetary discipline}

The administering of levy due to breach of budgetary discipline is untrusted to the Financial Administration Bodies with the provisions of Article 44a (11) of the Budget Rules. As outlined above in the administration of levy due to breach of budgetary discipline, the financial authorities act as tax authorities, conduct tax proceedings, assess the amount of levy and delay penalties due to breach of budgetary discipline, decide on appeals and supervisory measures, and conduct proceedings for remission of levy and a delay penalty due to breach of budgetary discipline.

This activity is disseminated within the three-tier system of financial administration bodies between the General Financial Directorate, the Appellate Financial Directorate and the Tax Offices in Territorial Departments.

The Tax Offices conduct their own tax controls ex officio according to the Tax Code. These checks are in grant projects mainly focused on compliance with conditions set by the grant provider and compliance with legal regulations. The grant recipient has the status of a tax 
entity and "is required by the Tax Code to provide Tax offices conducting on-the-spot checks with the necessary co-operation necessary to carry out on-spot-checks, borrow the requested documents to the Tax office officials and other things necessary for the checks" [Šretr 2011: 38]. In the case of a suspicion of a breach of budgetary discipline, the tax procedure is initiated and, in order to prove the breach of the budgetary discipline, the assessment of the levy and any delay penalty due to breach of the budgetary discipline is made. Another impulse for initiating tax proceedings to impose a levy due to breach of budgetary discipline is the initiative of another control authority, usually a grant provider. In this case, the procedure of the Tax Office depends mainly on the quality of the initiative and the probative value of the evidence. The inadequate quality of the initiative and, in particular, the lack of proof of the evidence found in the initiative, leads to the need to initiate tax control by the Tax Office. On the basis of the findings of such tax control, the Tax Office will issue an adjustment notice for a levy due to breach of budgetary discipline and the appropriate penalty and proceed with recovery of public funds.

The performance of this control is questionable and is the subject of public discussions on the elimination of control duplication and the effectiveness of the control system. From the point of view of the grant recipient, this control is identical, duplicate, with the control carried out by the grant provider, and means the administrative burden for him. In the process of recovering the unjustly used funds back into the public budget, the period from the discovery of the budget discipline breach to the actual return of funds to the public budget is extended.

The solution is to increase requirements to the activities of the other control authorities submitting the initiation of the procedure for imposing a levy due to breach of budgetary discipline. Even if the control authority is not in a position to decide whether a breach of budgetary discipline has occurred, it is its duty to properly justify its suspicion of a breach of budgetary discipline and to provide evidence. On the basis of initiative of the control authority and the evidence gathered, the Tax Office may initiate proceedings without the need for tax control, decide on a breach of budgetary discipline and assess the levy for the breach.

In order to consider the rights of the grant recipient and to speed up the process of returning unjustly used funds to the public budget, the Financial Directorate General has introduced an obligation for the Tax offices to use the assessment without control as much as possible. At present, the number of completed tax proceedings for the imposition of the levy due to breach of budgetary discipline without the need to conduct a tax control has stabilized at $20 \%$ share of all cases [Report of Financial Administration 2017].

Of course, the levy assessment without a tax control is not always possible. The recipient of the grant may submit new evidence to the tax office, which is inconsistent with the 
submitted documents from the control authority, who submitted the initiative. Tax offices have to make decisions in the that way, that it will endure the legal proceedings at courts. In the case of any doubts, Tax offices are obliged to carry out the tax control.

In the case of proven breach of budgetary discipline, the tax office issues an adjustment notice against which an appeal may be filed under the Tax Code. The appeal body is the Appellate Finance Directorate. In addition to appeals, the Appellate Finance Directorate further handles requests for review and proposals for authorization to renew the proceedings. The number of appeals submitted to the Appellate Finance Directorate increases each year, but relative to the total number of all adjustment notices issued, it is a relatively low proportion (for example in 2017 it was about 10\%).4

The Budget Rules offer under the Article 44a (12) the possibility of wholly or partially remission of levy and delay penalty due to breach of budgetary discipline on the basis of a request for remission. The levy and delay penalty may be remitted for reasons of special consideration. Such a reason may be, for example, the provider's fault, the provider's incoherence, the natural disaster, etc. The remission is decided by the General Financial Directorate. The General Financial Directorate also provides methodological help to the Tax Offices and to the Appellate Financial Directorate to manage the administration of levy due to breach of budgetary discipline and provides the sharing of experience and coordination of activities with grant providers.

\section{Influence of judicial jurisprudence on the activity of the Financial Administration Bodies in administering the levy due to breach of budgetary discipline}

The grant recipient is still more often taking legal action at administrative courts against the decision of the Financial Administrative Bodies. The Financial Administrative Bodies, following the jurisprudence of the administrative courts, adapt their activities and decisionmaking. One of the most fundamental changes in the decision-making of The Financial Administration Bodies is the transition to impose the levy due to breach of budgetary discipline in the amount of breach of budgetary discipline in accordance with the principle of proportionality [Matušková 2016: 86-95]. The shift in decision-making reflects the jurisprudence of the Supreme Administrative Court [Decisions No. 7 Afs 107/2008; No. 1 Afs 77/2010; No. 7 Afs 91/2013; No. 2 As 106/2014; No. 4 As 117/2014; No. 4 As 215/2014]. In its decision of 20 October 2014, No. 4 As 117/2014, the Supreme Administrative Court stated that "the purpose of the legal regulation of the provision of grants from public budgets is their proper use solely for the purpose intended in accordance with the general interest. In interpreting each particular provision, it is necessary to keep this meaning constant and to take it into account. Measuring the extent and severity of the breach of the conditions determined by the purpose of the grant does not go beyond the Act on budget rules, nor does 
it derogate from the statutory rules ... but it is essential for the constitutionally consistent, reasonable and proportionate application of this Act." Further in his decision states that "which grant conditions have been violated and whether it constitutes an unjustified use of funds from the state budget must always be considered on a case-by-case basis, considering all the specific circumstances and particularities of the individual case, not flat-rate and formalistic. The Supreme Administrative Court considers that it is not practical, sustainable and, moreover, it is not even in the interest of the grant provider to make grant recipient liable to pay the levy for every breach of the conditions."

The decisions of the Supreme Administrative Court, which deal with the definition of the Financial Administration Bodies position in relation to grant providers, are also fundamental. In the decision of the Supreme Administrative Court of 10 May 2017, No. 2 Afs 334/2016, it is stated that "the grant provider is not the one who determines whether the funds provided from the state budget have been legally used. Certainly, it is entitled to assess the achievement of the project's purpose, but it is often a purely technical question. These conclusions, however, are not binding to the tax administrator; if he finds a breach of the conditions, he is entitled and obliged to make decision based on it." Very important is also the statement "the territorial Tax Office has the exclusive competence to declare the breach of budgetary discipline" in the decision of the Supreme Administrative Court of the Supreme Administrative Court of 17 April 2017, No. 6 Afs 270/2015.

Financial authorities are under pressure and in a schizophrenic position for a long time. On the one hand, they are forced to unsure the returning of unjustly used funds back to the public budget and to eliminate the deficit that arises in the state budget after the recovery of funds for unjustly use back to the to the European Union, on the other side, their decisions are not confirmed by the administrative courts. Since the control of projects co-financed from European Union funds is partly governed by non-legislative guidelines of the European Union and the courts are strictly operating within the limits of the national legislation in force, this problem stays still unsolved.

\section{Strengthening the role of the grant provider and its impact on the activities of Financial Administration Bodies}

The results of the activity of the Financial Administration Bodies in the field of process of returning unjustly used funds back to the public budget are to a large extent influenced by the number of initiatives from the other control authorities. In the long run, the proportion of controls initiated on the basis of own search activity and the proportion of controls initiated on the basis of initiative is around $40 \%$ to $60 \%$. The overwhelming majority of the agenda consists of checking grant projects implemented from national sources or cofinanced from the European Union. The number of initiatives to start the procedure for 
imposing a levy due to budget discipline breach for projects co-financed by European Union funds before the year 2015 has steadily increased. As a result, some Tax offices were overwhelmed. In particular, the Prague Tax Office has carried out control activities in recent years solely on the basis of initiatives from other control authorities.

This undesirable effect was an impulse to modify legislation and strengthen the role of grant providers in the process of returning unjustly used funds back to the public budget.

The change was brought by the amendment of the Budget Rules in 2015, which significantly strengthened the roles of grant providers. Providers are given a wider opportunity to deal with unjustly used funds without the involvement of Financial Administration Bodies in the form of remedial measure or demand for grant repayment under the Article $14 \mathrm{f}$ of the Budgetary Rules. At the same time, the provider's competence to refuse the payment of grant or its part was extended with the provisions of Article 14e to the cases when he considers that the recipient has breached the obligations stipulated by the legal regulation or failed to meet the purpose of the grant or the conditions under which the grant was provided.

Article $14 \mathrm{f}$ is intended for cases when the grant provider concludes that the identified deficiencies can be solved by corrective actions or reimbursement of the grant or its part without the involvement of the Financial Administration Bodies. To the extent that the grant recipient makes a corrective action or returns the grant on the basis of the demand within the deadline set by the provider, there is no breach of budgetary discipline, and the Financial Administrative bodies are no longer acting on the matter. Whether or not the beneficiary will repay the grant or whether it will make a corrective action is entirely at its discretion. The Provider has no enforceable means and has no power to recover the grant and enforce the corrective actions. At this point, the Financial Administration Bodies are again entering the process. At the initiative of the provider, the Tax Office decides in standard tax proceedings to impose a levy due to budget discipline breach. The initiative to the Tax Office must also be sent by the provider if only part of the required grant has been repaid or if the correction has been incomplete and if the demand has not been met within the set deadline.

Budgetary rules do not specify a time period within which a grant provider can use the measure under Article $14 \mathrm{f}$ what causes practical problems for already initiated controls and proceeding by the Tax Offices. In a few cases, the Tax Office initiated a tax control and proceeding to impose a ley due to breach of budgetary discipline, but the provider then demanded the recipient to return the grant and the recipient complied with the demand. In this case, the breach of budgetary discipline has been healed, so the Tax Office has no longer been given the decision-making power. The lack of legislative regulation is the 
subject of expert consultation and the possible analogy with the Institute of effective regret ${ }^{1}$ according to Penal Code is considered. According to this theory, the latest date for the implementation of the measure under the Article $14 \mathrm{f}$ would be the issue of the adjustment notice (analogous to the decision of the first instance court). This is not a complete elimination of the problem of unnecessary burden in administering a levy due to breach of budgetary discipline by the Tax Office in the event of a subsequent grant repayment to the provider. It can therefore be concluded that the legal status de lege lata should suit the possibility of taking measures under Article $14 \mathrm{f}$ until the tax authority issues the adjustment notice, but for legal status de lege ferenda is more likely to limit this possibility to the Tax Office's initiation of tax control.

The possibility for the grant provider to refuse grant payment to the beneficiaries was included in the Budgetary Rules before the 2015 amendment. The grant provider was competent to use this measure only in case of breach of the public procurement rules for projects co-financed by European Union funds. The Tax Office could then count off amounts that the grant provider has not yet paid, assuming that budget discipline has been breached. The amendment to the budgetary rules extended this power to all cases where the grant provider reasonably believes that the recipient of the grant in relation to a not yet paid grant breached the obligations laid down by the law or failed to meet the purpose of the grant or the conditions under which the grant was provided. Of course, in the case of non-repayment of funds, unjustly use of public funds and breach of budgetary discipline could not occur, therefore, there is not competence for the Financial Administration Bodies to act in this case. The application of the provisions of Article 14e for projects with a one-off ex-post financing works more or less without any problems. However, the situation is more complicated in cases where the provider applies this measure in relation to the funds already paid. These cases occur with the ongoing ex-ante financing of the project, where the disbursement of funds is ongoing. Therefore, there may be a situation where the provider discovers the unjustified use of already paid funds and decides not to redeem other funds. At this point, the Financial Administration bodies are again entering the process. In the standard procedure for imposing a levy due to breach of budgetary discipline, the Tax Office will decide whether the breach has occurred. The decision of the Tax office is then binding the provider. If the Tax Office fails to prove a breach of budgetary discipline, the grant provider is required to pay the unpaid funds to the grant recipient. These conclusions were made by the Enlarged Senate of the Supreme Administrative Court [Decision No. 6 Afs 270/2015] in a matter that concerns the Budget Rules prior to the 2015 amendment, but its conclusions can be applied by analogy to the

\footnotetext{
${ }^{1}$ [Criminal Code, art. 242]: Criminal liability for the offense of tax evasion, social security and similar compulsory payments (Article 241) shall be ceased if the offender has fulfilled his obligation retroactively before the court of first instance has commenced the declaration of its decision.
} 
current legal status. The decision of the provider not to pay the grant becomes temporary, and participation of the Tax Office is inevitable for the final decision.

The fundamental problem arising from the inadequate adjustment in the Budget Rules is the impossibility for the Tax Office to count off unpaid grant into the adjustment notice of levy due to breach of budgetary discipline. The grant recipient is affected by the fact that the grant has not been paid out by the provider and also by the obligation to pay the levy to the Tax Office. There is, therefore, a double penalty for the grant recipient, which of course needs to be resolved by other legal means.

The solution that is primarily offered is the limitation of the provider's right to refuse the grant payment only in relation to the not yet paid funds. Fundamentally, however, the grant providers disagree and refuse to pay funds to recipients who already, for example, broke the conditions of the grant provided in the ongoing grant financing. The Financial Administrative Bodies welcomed the aforementioned decision of the Enlarged Senate of the Supreme Administrative Court. In spite of the remaining uncertainties, they proceed fully in line with this decision and engage in the process of recovering unjustly used public funds into the public budget even if the provider has not paid the funds in relation to already paid grants.

At the end of this chapter it can be concluded that according to the latest statistics from the General Financial Directorate of 2017, the share of control of projects co-financed by the European Union funded funds is only $24.5 \%$ of the total number of controls carried out by the Tax Offices, compared to $68.8 \%$ in 2016 . The possibility of the grant provider, without the involvement of the Financial Administration bodies, to refuse the grant payment to the recipient or to demand the grand repayment under Article 14e and Article 14f of the Budgetary Rules contribute to this decline.

\section{An attempt to remove the Financial Administrative bodies from the process of returning unjustly used public funds back into the public budget}

In 2015, the Ministry of Finance introduced a new concept of the procedure for returning public funds back to the public budget [Matušková 2015: 586-592]. As part of the new legislation in the Bill on internal management and control of public finances, an amendment to the Budgetary Rules was proposed in the Amending Act, which undermined the competence of the Financial Administration Bodies to administer the levy due to breach of budgetary discipline. The activities of the financial administration were supposed to be carried out by grant providers, the Ministry of Finance and the Customs Administration. The right to impose the levy due to breach of budgetary discipline and collect the public funds back to the public budget, according to the amendment, fell within 
the competence of the grant providers - the control authority, the appeal proceedings within the competence of the Ministry of Finance and the possible enforcement within the competence of the Customs Administration.

The proposed amendment aimed at eliminating duplicate controls of grant recipients by both the provider and the Tax Office and reducing the administrative burden resulting therefrom. By eliminating the tax control, the time from the discovery of a breach of budgetary discipline to the recovery of public funds back to the public budget should have been shortened. The Ministry of Finance has also sought to resolve this discrepancy between the findings of control authorities on the one hand and the Tax Offices on the other. In the case of funds provided from European Union funds, unjustly used funds are returned to the budget of the European Union, but this loss is not subsequently compensated by the recovery of funds from the grant recipient.

The legally designed new concept of the procedure for returning public funds back to the public budget was resolutely rejected by the Financial Administration Bodies and grant providers. Subsequent public consultations have shown that this change will not achieve the objectives set and, on the contrary, can bring additional procedural complications, increase administrative burdens and costs to the detriment of the state budget as well as the budget of the grant recipients.

The Financial Administrative Bodies are independent bodies with a three-tier structure that ensures uniform methodical guidance by the Financial Directorate General, independent decision-making on corrective and supervisory means. At the same time, the financial administration has trained control officers in the regions at the Tax Offices and an experienced apparatus in the field of representation before the administrative and civil courts.

One of the main reasons for the unacceptability of the proposed regulation was the fragmentation of the powers of the public authorities between a large number of control bodies (providers), the Ministry of Finance and the Customs Administration. In addition, it would be necessary to apply several procedural rules (the Control Code, the Administrative Code and the Tax Code) when carrying out these activities. Last but not least, the new competencies, especially in the control authorities, would mean a substantial increase in the agenda - management of the levy administration and the collection of funds. This requires an increase in staffing capacities. The control authorities do not usually have their workplaces in regions, as is the case with The Financial Administration Bodies. It is therefore unavoidable to increase travel costs. Here are just the most fundamental contradictions the proposal has raised. The failure of the new concept was essentially inevitable, and the Ministry of Finance itself resigned from its proposal. 
From the above, it appears that the role of the Financial Administration Bodies is currently irreplaceable in the process of returning the unjustly used public funds back to the public budget. Any changes should be preceded by rigorous expert discussion and detailed process and cost analyses in the future. At present, no intervention in the competences of the Financial Administration Bodies in this area is expected.

\section{Conclusion}

With this brief summary of the activity of the Financial Administrative Bodies in administering the levy due to the breach of budgetary discipline, I tried to show the troublesome position of the Financial Administration Bodies in the process of returning unjustly used public funds back to the public budget. In conclusion must be stated that the current setting of this process with the involvement of the Financial Administrative Bodies remains in the legal environment of the Czech Republic the most stable and effective for achieving the stated goal.

\section{References:}

Grossová, Marie Emilie: Finanční právo se zaměřením na daňové právo. Ostrava: KEY Publishing s. r. o., in co-edition with B.I.B.S., a.s., Brno, 2008

Matušková, T.: Proporcionalita odvodu za porušení rozpočtové kázně př́ijemcem dotace. Právní rozhledy, ed. Vol. 24, no. 3 (2016)

Matušková, T.: Dopad novely rozpočtových pravidel do sféry př́jemců dotací a související judikatura. Právní rozhledy, Vol. 23, no. 17 (2015)

Šretr, Vladimír: Daňová kontrola z pohledu daňového řádu. Praha: Linde Praha a. s., 2011

The Annual Report Of Financial Administration 2017, http://www.financnisprava.cz/en/financial-administration/annual-reports

\section{Legislation and judicial jurisprudence:}

Act No. 218/2000 Coll., on Budget Rules

Act No. 250/2000 Coll., on Budget Rules of Municipality Budgets

Act No. 280/2009 Coll., Tax Code

Act No. 40/2009 Coll, Criminal Code

Decision of The Supreme Administrative court No. 1 Afs 77/2010

Decision of The Supreme Administrative court No. 2 As 106/2014

Decision of The Supreme Administrative court No. 4 As 117/2014

Decision of The Supreme Administrative court No. 4 As 215/2014

Decision of The Supreme Administrative court No. 7 Afs 107/2008

Decision of The Supreme Administrative court No. 7 Afs 91/2013 